\title{
The Netflix-ication of sports broadcasting
}

\author{
Johan Lindholm ${ }^{1}$
}

Published online: 22 February 2019

(c) T.M.C. Asser Instituut 2019

Sports and television have been involved in a close relationship for as long as anyone alive can remember. In August 1936, 150,000 individuals visited public viewing rooms in Berlin to watch live broadcasts of the 1936 Summer Olympics. ${ }^{1}$ Who would have predicted that this seemingly minor event would be the first in a chain of events that would radically affect both sports and television?

The relationship between sports and television has for the most part been mutually beneficial and has, for the most part, only grown deeper over time. Television allowed sports to reach audiences that are too far away to attend sporting competitions live. Broadcasting brought sports audiences of previously unattainable, even unimaginable sizes, far greater than what could fit in any stadium. For example, last summer, approximately 3.6 billion individuals, more than half of the world's population, watched the FIFA World Cup. ${ }^{2}$ The medium of television has contributed to making sports mega events, like the FIFA World Cup and the Olympic Games, part of a globally shared cultural sphere. ${ }^{3}$

Broadcasting has changed sports, for good and for bad, turning it into one of the main forms of entertainment and turning athletes into global celebrities. As one author describes it, "the world of sports in the age of mass media has been transformed from nineteenth-century amateur

\footnotetext{
${ }^{1}$ It was a stroke of tremendous irony that this broadcast, which the Nazi regime had organized for propaganda purposes, featured African-American athlete Jesse Owens winning the 100-m final.

2 FIFA, "More than half the world watched record-breaking 2018 World Cup," December 21, 2018. https://www.fifa.com/worldcup/ news/more-than-half-the-world-watched-record-breaking-2018-world -cup. Accessed January 19, 2019.

${ }^{3}$ See, e.g., Roche 2006.
}

Johan Lindholm

johan.lindholm@umu.se

1 Department of Law, Umeå University, 90187 Umeå, Sweden recreational participation to late twentieth-century spectatorcentered technology and business. ${ }^{, 4}$ Sports has also changed television as sports has expanded into an evermore central position in television programming, at least in financial terms. For example, worldwide broadcasters paid the Olympic movement 88 million USD for the rights to televise the 1980 Moscow Olympic Games. By comparison, the broadcasting rights to the 2016 Rio Games sold for almost thirtythree times more: 2868 million USD. ${ }^{5}$ The steep increase in price of sport broadcasting rights is a testament to sports' ability to capture audiences' attention to an extent and in a way with which very few other activities can compete.

One should not, however, interpret television networks' willingness to pay repeatedly record-breaking amounts for sports broadcasting rights as a testament to the long-term strength and health of the sports-television relationship. For a long time, the competition-driven price increases for exclusive sports broadcasting rights were primarily motivated by television networks competing with each other for consumers' attention. There is a low level of substitutability between sport broadcasts and other, alternative programming options, ${ }^{6}$ and sports broadcasts acted as exclusive attention drivers for the networks who were able to convert that attention into advertising revenues, subscription fees and pay-per-view fees. Because of this, winning bidding wars for broadcasting rights would generally be profitable for the broadcaster, albeit not always. ${ }^{7}$

Two more recent developments have had a significant impact on the sports media industry. The first is the

\footnotetext{
${ }^{4}$ Real 1998, p. 18.

${ }^{5}$ IOC, Olympic Marketing Fact File, 2019 Edition. https://stillmed. olympic.org/media/Document\%20Library/OlympicOrg/Documents/ IOC-Marketing-and-Broadcasting-General-Files/Olympic-MarketingFact-File-2018.pdf. Accessed January 19, 2019.

${ }^{6}$ See, e.g., Commission Decision of July 23, 2003, relating to a proceeding pursuant to Article 81 of the EC Treaty and Article 53 of the EEA Agreement (COMP/C.2-37.398-Joint selling of the commercial rights of the UEFA Champions League), OJ L 291/25, November 8, 2003.

7 See, e.g., Feuillet et al. 2018.
} 
globalization of sports consumption. Thirty years ago, a few, large sporting events would have an international viewership, although nowhere near the global viewership of today, and sports fans would otherwise largely consume sports from their own country or region. But things changed quickly and dramatically in the 1980s and 1990s. ${ }^{8}$ For example, whereas the 1980 Moscow Olympic Games could be seen in 111 nations, the 2000 Sydney Olympic Games were broadcasted globally. ${ }^{9}$ The Premier League is perhaps the most extreme example of this. When the league was formed in 1992, the international interest was so low that the league paid the broadcasters to show the games ${ }^{10}$; in the latest cycle, the international broadcasting rights sold for more than one billion USD per year. ${ }^{11}$

A second major change in recent years is the technological development that allows for streaming video over the internet on a large scale. This particularly consists of an infrastructure development that provides a larger portion of the world's population with high-speed internet access. Many individuals may primarily associate online video streaming with watching clips, TV shows and movies through major online platforms. However, the online streaming revolution also has had a quick and quite dramatic impact on how sports are consumed. In 2008, 400 million individuals used the internet to watch the Beijing Olympic Games. Only 4 years later, in time for the 2012 London Olympic Games, that number had rose to an impressive 1.2 billion individuals. ${ }^{12}$

The television industry, including the segment involved in sports broadcasting, has had to adapt to the fact that the public is now to a significant extent consuming video entertainment online rather than through television channels. Television networks have for a long time used exclusive live sports coverage in competing with each other for viewers' interest and subscription fees. ${ }^{13}$ More recently, these networks have also used such broadcasts to keep their viewers' attention while competing with online actors like Netflix, exploiting the fact that live broadcasts of sporting events are not readily interchangeable in the eyes of consumers for other types of video entertainment. The technological development has brought with it a slew of legal issues, particularly in the realm of intellectual property law.

As significant as this development has already been for the sports broadcast business, we have likely still only begun

\footnotetext{
${ }^{8}$ See Gratton and Solberg 2007, pp. 1-10.

${ }^{9}$ IOC 2019.

10 The Guardian, "How a deluge of money nearly broke the Premier League," January 17, 2019.

11 Deloitte 2018, p. 17.

12 IOC 2019.

13 Gratton and Solberg 2007, pp. **.

to see the disruptive effects of the sports streaming revolution. Such development has reduced the barriers to enter the market, leading to more competition and to value moving upstream, from the broadcasters to the rights owners. ${ }^{14}$ In recent years, both online giants like Facebook and Hulu and less well-known startups have started competing for broadcasting rights, each vying to become the "Netflix for sports." This development has significantly expanded in the last 2 years. For example, in May 2018, a UK-based company, DAZN, made a statement when it paid 1 billion USD for boxing broadcasting rights. ${ }^{15}$

The biggest splash, however, was made by Amazon. Amazon launched Amazon Prime in 2005 as a fast-shipping subscription service for its online retail business, but today the service is bundled with Amazon's video and music streaming service that the company has offered since 2006. Amazon Prime, Netflix, and other similar streaming service providers have thus far focused on providing on-demand video, foregoing live broadcasts, including live broadcasts of sporting events. This has changed in recent years, with Amazon leading the way. Since 2017, Amazon has had an agreement with the National Football League (NFL) to broadcast a number of professional American football games each season in the USA. It also won the bid to show ATP tour tennis in the UK, beating the Sky television network to procure the exclusive rights. ${ }^{16}$ The biggest headlines, however, were made last summer when Amazon procured some of the most coveted and expensive sports broadcasting rights: the exclusive right to broadcast twenty Premier League games in the UK. ${ }^{17}$

These events significantly increase the likelihood of a coming "Netflix-ication" of sports broadcasting. Such a development could help resolve some of the legal issues that have followed from the technological development. For example, the same technical development that makes it easy for broadcasting rights holders to livestream sporting events allows for unauthorized "pirate" streaming. ${ }^{18}$ The introduction of subscription-based music streaming services, like Spotify and Apple Music, has helped reduce online music

\footnotetext{
${ }^{14}$ Gratton and Solberg 2007, pp. 9-10.

15 The Guardian, "UK-based sport streaming service adopts Netflix model after \$1bn deal," May 14, 2018.

16 The Guardian, "Amazon outbids Sky to win exclusive ATP tour tennis rights," August 1, 2017; The Telegraph, "Amazon continues foray into tennis broadcasting with UK rights to US Open for next five years," November 15, 2017.

17 New York Times, "Amazon Wins Exclusive U.K. Rights to Broadcast Some Premier League Matches," June 7, 2018.

18 See, e.g., Horner 2014; Kariyawasm and Tsai 2017; Robertson 2015.
} 
piracy, and subscription-based sports streaming services could have a similar effect. ${ }^{19}$

That additional, well-funded actors enter the competition for sports broadcasting rights is likely to push already astronomical prices to increase even further. This, in turn, will fuel some of the related problems and conflicts, including legal problems and conflicts, such as disputes over ownership of broadcasting rights and the division of proceeds from collective selling of broadcasting rights. Also, although the agreements Amazon has struck thus far are limited to broadcasting in particular nations, Amazon, like Netflix, is available in all but a few of the world's countries, dwarfing even the largest television networks in term of global reach. A "Netflix-ication" of sports broadcasting would thus further add to the globalization of sports consumption.

Companies like Amazon entering the business of live sports broadcasting do not, however, only intensify already ongoing development in the business. Depending on how much they choose to focus on sports broadcasting, they can potentially disrupt the market on a more fundamental level. Amazon (and similar online service providers that may choose to become involved) do not operate under quite the same financial limitations as television networks when bidding for broadcasting rights. Following its overall business model, Amazon has been and is losing large amounts of money on Amazon Prime, according to some estimates billions of US dollars annually. Amazon offers consumers its services at a loss with the goal of not only establishing a significant market share but market dominance, and persuading consumers to buy into Amazon Prime is a crucial element of that strategy. ${ }^{20}$ Thus, to Amazon, broadcasting sporting events does not need to be a profitable business as such. Rather, it is primarily a means for driving consumers to its whole range of services, thereby strengthening its position in those sectors. Amazon would also be able to use information gathered about viewers in its other businesses and to steer viewers to its sports-related businesses. ${ }^{21}$ It is easy to see how Amazon's ability to recuperate losses on broadcasting rights, by merit of its size and business model, could quite quickly develop into a situation where television networks, even well-established actors in the field, may have a very difficult time competing for sports broadcasting rights.

It is difficult to fully gauge what such a shift would mean in the long run. Khan argues that Amazon's business model is harmful to the market, at least in the long run, and that competition law is ill-equipped to handle this new type of practice. ${ }^{22}$ If so, Amazon's recent purchases of broadcasting rights, limited as they are, could forebode a more dramatic and not necessarily healthy shift in the sports media market.

\section{References}

Deloitte 2018. Roar power-annual review of football finance 2018. https://www2.deloitte.com/content/dam/Deloitte/cz/Documents/ consumer-business/cz_annual_review_of_football_finance_2018. pdf. Accessed 12 Feb 2019

Feuillet A, Scelles N, Durand C (2018) A winner's curse in the bidding process for broadcasting rights in football? The cases of the French and UK markets. Sport Soc. https://doi.org/10.1080/17430 437.2018.1505869

Grafton C, Solberg HA (2007) The economics of sports broadcasting. Routledge, Oxon

Horner SN (2014) DMCA: professional sports leagues' answer to protecting their broadcasting rights against illegal streaming. Marquette Sports Law Rev 24:435-462

Kariyawasm K, Tsai M (2017) Copyright and live streaming of sports broadcasting. Int Rev Law Comput Technol 31(3):265-288

Khan LM (2017) Amazon's antitrust paradox. Yale Law J 126:710-805

Real MR (1998) MediaSport: technology and the commodification of postmodern sport. In: Wenner LA (ed) MediaSport. Routledge, London, pp 14-26

Robertson A (2015) Internet piracy of sports broadcasts: finding the solution in the United Kingdom and the United States. Marquette Sports Law Rev 25:469-490

Roche M (2006) Mega-events and modernity revisited: globalization and the case of the olympics. Sociol Rev 54:27-40

Walker CS (2012) A la carte television: a solution to online piracy? Cathol Univ J Law Technol 20:471-494

Publisher's Note Springer Nature remains neutral with regard to jurisdictional claims in published maps and institutional affiliations.

\footnotetext{
$\overline{19}$ Walker 2012.

20 Khan 2017, p. 747-753.

${ }^{21}$ For example by promoting the sale of team gear.

22 Khan 2017.
} 